\title{
Communication of bad news in pediatrics: integrative review
}

\author{
Comunicação de más notícias em pediatria: revisão integrativa \\ Comunicación de malas noticias en pediatría: revisión integrativa
}

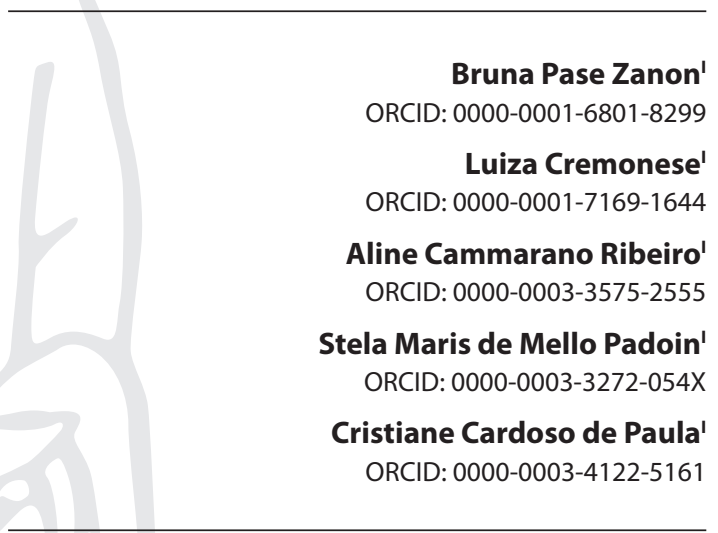

'Universidade Federal de Santa Maria. Santa Maria, Rio Grande do Sul, Brazil.

How to cite this article:

Zanon BP, Cremonese L, Ribeiro AC, Padoin SMM, Paula CC. Communication of bad news in pediatrics: integrative review. Rev Bras Enferm. 2020;73(Suppl 4):e20190059. doi: http://dx.doi.org/10.1590/0034-7167-2019-0059

Corresponding author:

Cristiane Cardoso de Paula

E-mail: cristiane.paula@ufsm.br

EDITOR IN CHIEF: Dulce Aparecida Barbosa ASSOCIATE EDITOR: Priscilla Valladares Broca

Submission: 03-13-2019

Approval: 07-30-2019

\section{ABSTRACT}

Objectives: to identify the scientific evidence of the elements of communication in the process of communicating bad news in pediatrics. Methods: integrative review searched in the LILACS, PubMed and WoS databases. Primary studies in Portuquese, Spanish or English were included. Results: the evidence from the 40 studies were organized according to the elements of communication: sender (family and/or professional), receiver (family and/or child), message (bad or difficult news about diagnosis/prognosis; empathetically, honestly, objective, hopeful and available), channel (materials, quality, quantity and pace), context and effects (social and emotional changes), noise (feelings and language) and failures (silencing and misleading information). Conclusions: there is a need to prepare the institution and team, as well as the family and the child, in order to promote co-responsibility in this process, to minimize suffering and communication noise and to avoid failures, recognizing the child's right to know their condition.

Descriptors: Truth Disclosure; Health Communication; Diagnosis; Child Health; Pediatrics.

\section{RESUMO}

Objetivos: identificar as evidências científicas dos elementos da comunicação no processo de comunicação de más notícias em pediatria. Métodos: revisão integrativa nas bases de dados LILACS, PubMed e WoS. Foram incluídos estudos primários, em português, espanhol ou inglês. Resultados: as evidências dos 40 estudos foram organizadas de acordo com os elementos da comunicação: emissor (família e/ou profissional), receptor (família e/ou criança), mensagem (notícias ruins, más ou difíceis sobre diagnóstico/prognóstico; de modo empático, honesto, objetivo, esperançoso e disponível), canal (materiais, qualidade, quantidade e velocidade), contexto e efeitos (alterações sociais e emocionais), ruídos (sentimentos e linguagem) e falhas (silenciamento e informações enganosas). Conclusões: há necessidade de preparação da instituição e equipe, bem como da família e da criança, de modo a promover a corresponsabilização nesse processo, minimizar o sofrimento e os ruídos de comunicação e evitar as falhas, reconhecendo o direito da criança de saber de sua condição.

Descritores: Revelação da Verdade; Comunicação em Saúde; Diagnóstico; Saúde da Criança; Pediatria.

\section{RESUMEN}

Objetivos: identificar las evidencias científicas de los elementos de la comunicación en el proceso de notificación de malas noticias en pediatría. Métodos: se trata de una revisión integradora realizada en las bases de datos LILACS, PubMed y WoS, con estudios primarios en portugués, español e inglés. Resultados: las evidencias de los 40 estudios se organizaron según los elementos de la comunicación: emisor (familiar y/o profesional), receptor (familiar y/o niño), mensaje (noticias dolorosas, malas o difíciles sobre el diagnóstico/pronóstico; de manera empática, honesta, objetiva, esperanzadora y disponible), canal (materiales, calidad, cantidad y rapidez), contexto y efectos (cambios sociales y emocionales), ruido (sentimientos y lenguaje) y fracaso (silencio e información engañosa). Conclusiones: es necesario preparar a la institución y al equipo, así como a la familia y al niño, para promover la corresponsabilidad, amenizar el sufrimiento y las interferencias en la comunicación y evitar los fracasos, reconociendo el derecho del niño de saber sobre su condición.

Descriptores: Revelación de la Verdad; Comunicación en Salud; Diagnóstico; Salud del Niño; Pediatría. 


\section{INTRODUCTION}

In daily health care, professionals often experience the challenge of communicating news that can be considered bad or difficult, which causes sadness, discontent, anxiety and grief, among other distressing feelings. Such news refers to the true disclosure of an information that causes a negative and intense change in the perspective of the future. In the health area, it may be related to a threat to the physical or mental state, with emphasis on diagnoses of illnesses with reserved prognosis, severe sequelae, depletion of current healing resources and preparation for palliative care ${ }^{(1)}$.

Communicating this type of news must involve the health team, as each profession has specific duties and skills. It is worth noting that the effectiveness of the communication process depends on the link between those involved and on the professional's sensitivity to manage each situation; it also depends on cultural, social, educational and family contexts ${ }^{(2-4)}$.

Such issue stands out as a problem in the pediatric context, since the communication of bad news is even more complex, as it involves both the family and the child. It requires an assessment of the quantity and quality of information that will be communicated and the way to develop it, considering the child's intellectual, cultural and psychological singularity ${ }^{(5)}$. This reinforces the importance and indicates the need for evidencebased practice, as it enables the search for strategies that can be used by health professionals in such communication.

The communicative process involves elements that are named as follows: SENDER, represented by someone who sends the message; RECEIVER, who receives the information; MESSAGE, which is the content; $\mathrm{CHANNEL}$, means used for communication; and CONTEXT $^{(6-7)}$. The structure and functioning of these elements are the focus of studies in the Communication field and can be applied in the Health area. This model is a pioneer, proposed by Lasswell, and the author is considered one of the main theorists of communication. There are other communication propositions that go beyond the traditional one, and recognize factors such as the production of meaning, ideology and group and identity belonging ${ }^{(6)}$.

For communication to be effective, messages must be sent in a sufficiently clear and detailed manner, with codes that the receiver understands and with appropriate terms. Factors that may interfere with the communicative process, such as education, cognition, culture and age, should be considered. Thus, communication can occur with noise, which may impair the way the message is understood or prevent it from happening ${ }^{(6)}$.

Such failures can be considered when professionals do not feel prepared to communicate the diagnosis/prognosis, which can lead to silencing, false promises of treatment/cure or abrupt communications, with damages to the therapeutic relationship ${ }^{(8)}$.

\section{OBJECTIVES}

To identify evidence of the elements of communication in the process of communicating bad news in pediatrics.

\section{METHODS}

This is an integrative review of the literature, which aims to synthesize the scientific knowledge on a specific topic, in order to contribute to the state of knowledge of a particular area and to the evidence-based practice. The six following steps were developed: (a) selecting the hypotheses or questions for the review, (b) sampling of the research to be reviewed, (c) representing the characteristics of the studies and their findings, $(d)$ analyzing the findings, (e) interpreting the results and (f) reporting the review ${ }^{(9)}$.

In order to select the question for the review, it was considered that communicating bad news is a challenge both for professionals and for the family and children. However, there are few guidelines for the development of this process. The review question was: "What are the evidence of the elements of communication in the process of communicating bad news in pediatrics?". The choice for this traditional communication model is justified based on the content available in the primary articles included in this review.

In order to establish the sample, the inclusion criteria were: primary studies in Portuguese, Spanish or English, that addressed communication about the child's health condition. The exclusion criteria were: maternal or paternal diagnosis, pregnancy diagnosis, death of the child or family member, sexual abuse, temporary situation, procedure and simulations; no specific period was established. For the choice of the Medical Subject Headings (MeSH) and the Health Sciences Descriptors (DeCS), in order to expand the retrieval of documents in the databases, a mapping of the descriptors/keywords of articles about communication of difficult news or bad news in pediatrics was developed, as well as of the words used in the titles and abstracts that indicated the theme. The search strategy was tested by the reviewers, discussed in the Research Group and assessed by the librarian. The search strategy was based on the MeSH/keywords [disclosure OR truth disclosure OR health communication] AND [diagnosis OR CID OR news] AND [difficult OR bad] AND [child OR pediatrics OR infant], and DeCS/words [revelação OR revelação da verdade OR comunicação em saúde] AND [diagnóstico OR CID OR notícias] AND [difíceis OR más] AND [criança OR pediatria OR infantil], with combinations adjusted to each base.

The search was developed in January/2018 in the Latin American and Caribbean Health Sciences (LILACS), National Library of Medicine, National Institutes of Health (Pubmed) and Web of Science (WoS) databases. The study selection was developed independently by two reviewers with a subsequent consensus meeting with a third reviewer. The reviewers were trained in a bibliographic research course, offered annually by the Research Group.

The identification resulted in a total of 321 studies in the databases. The references indexed in more than one database were included once, avoiding repetition. The selection was developed by reading the titles and abstracts, whereas eligibility was conducted by reading the entire text. The inclusion reached 40 articles as a corpus of analysis (Figure 1). For articles that were not found fully available in the databases, the strategies for accessing the full text were exhausted, through contact with the authors and home institutions of the study.

The data extraction for each article included in the review was registered in an Excel instrument with the following information: reference, country in which the study was conducted, method, results of communication about the child's health condition and level of evidence. In order to determine the level of evidence, the application of the hierarchy considered the type of research question in the primary study: Intervention or diagnosis; Prognosis or etiology; Meaning ${ }^{(10)}$. 


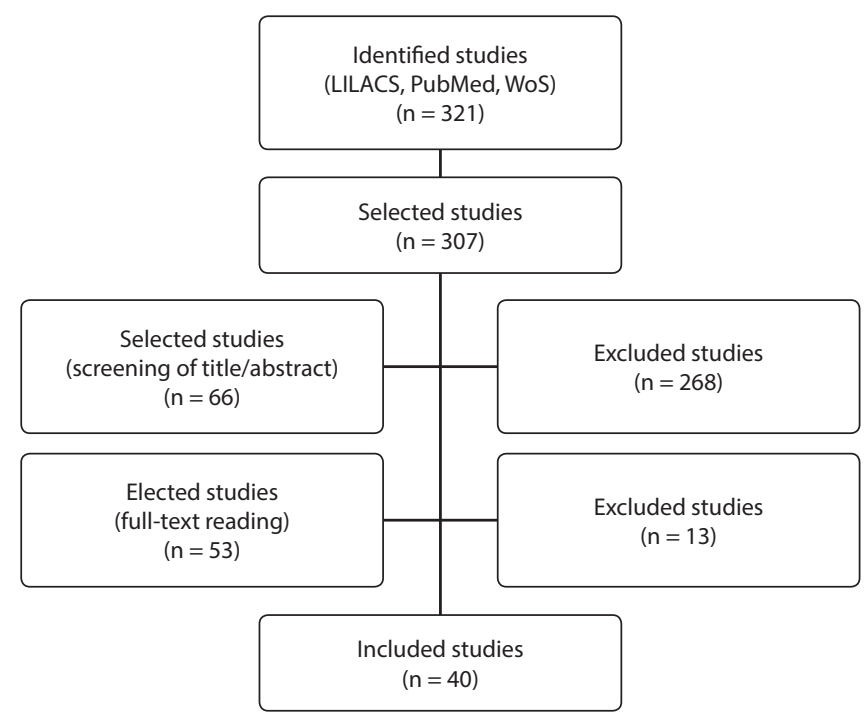

Figure 1 - Flowchart of the process of identification, selection, eligibility and inclusion in the integrative review of communicating bad news in pediatrics, Brazil, 2018

For the step with regard to representing the characteristics of the studies, the data were described in a table with objective, design, participants and level of evidence. In order to analyze the findings, the evidence of the elements of communication (sender, receiver, context, message, channel, feedback, noise and failures) were highlighted in the results of each article. Subsequently, the evidence were grouped by convergence and counterpoint, which generated the synthesis. Finally, the results of the integrative review were described and discussed, culminating in considerations of assistance, educational and investigative practices for communicating bad news in pediatrics. The citation Norms of the Brazilian Technical Standards Association (ABNT) were followed, referencing the authors and the Copyright Law (No. 9160 of February 19, 1998).

\section{RESULTS}

The characteristics (objective, study design, participants and level of evidence) of the studies included in the integrative review are presented in order to contextualize the extracted evidence to answer the review question (Chart 1). The critical appraisal pointed out that the articles have the research question directed to meaning and experience, mostly with level of evidence 2 , followed by 4 . No intervention-type articles were retrieved.

The evidence of the elements of communication (sender, receiver, context, message, channel and feedback) in the process of communicating bad news in pediatrics, that were extracted from the results of each article included in the review, are presented in Chart 2.

The extracted evidence were grouped according to the traditional communication model ${ }^{(7)}$ and generated the synthesis represented in Figure 2.

Chart 1- Characterization of articles included in the integrative review of communication of bad news in pediatrics, Brazil, 2018

\begin{tabular}{|c|c|c|c|c|}
\hline ID & Year/Country & Objective & Study Design & EL \\
\hline (11) & $\begin{array}{l}2017 / \\
\text { Brazil }\end{array}$ & $\begin{array}{l}\text { To understand the management of emotions involved in the } \\
\text { relationship between doctors, mothers, and children in the } \\
\text { experience of sharing difficult news in a pediatric and hematological } \\
\text { oncology service. }\end{array}$ & $\begin{array}{l}\text { Descriptive qualitative. } \\
\text { P: } 9 \text { doctors and } 5 \text { mothers. }\end{array}$ & $2^{*}$ \\
\hline (12) & $\begin{array}{l}2007 / \\
\text { USA and Japan }\end{array}$ & $\begin{array}{l}\text { To describe patterns of communication at diagnosis between } \\
\text { pediatric oncologists and children with cancer and to compare } \\
\text { cultural differences in these practices in the US and Japan. }\end{array}$ & $\begin{array}{l}\text { Cross-sectional quantitative. } \\
\text { P: } 350 \text { US and } 362 \text { Japanese } \\
\text { pediatric oncologists. }\end{array}$ & $4^{*}$ \\
\hline (13) & $\begin{array}{l}2010 / \\
\text { Israel }\end{array}$ & $\begin{array}{l}\text { To assess parents' experiences with receiving the bad news of the } \\
\text { detection of their child's hearing loss. }\end{array}$ & $\begin{array}{l}\text { Descriptive qualitative. } \\
\text { P: } 14 \text { families/parents. }\end{array}$ & $2^{*}$ \\
\hline (14) & $\begin{array}{l}2003 / \\
\text { Australia }\end{array}$ & $\begin{array}{l}\text { To explore parents' experience of being told that their child had a } \\
\text { condition, such as bone dysplasia, that would result in significant } \\
\text { short stature. }\end{array}$ & $\begin{array}{l}\text { Descriptive qualitative. } \\
\text { P: } 11 \text { family members. }\end{array}$ & $2^{*}$ \\
\hline (15) & $\begin{array}{l}\text { 2010/ } \\
\text { Sweden }\end{array}$ & $\begin{array}{l}\text { To describe the main concern of physicians facing malignant } \\
\text { disorders, psychosocial issues and existential provocation; and } \\
\text { strategies for handling these challenges. }\end{array}$ & $\begin{array}{l}\text { Qualitative, Grounded Theory. } \\
\text { P: } 10 \text { physicians. }\end{array}$ & $2^{*}$ \\
\hline (16) & $\begin{array}{l}2014 / \\
\text { USA }\end{array}$ & $\begin{array}{l}\text { To examine primary care provider experiences with the initial } \\
\text { parental disclosure of cystic fibrosis newborn screening results } \\
\text { in order to identify methods to improve parent-provider } \\
\text { communication during the process. }\end{array}$ & $\begin{array}{l}\text { Descriptive qualitative. } \\
\text { P: } 10 \text { primary care providers. }\end{array}$ & $2^{*}$ \\
\hline (17) & $\begin{array}{l}2014 / \\
\text { Iran }\end{array}$ & $\begin{array}{l}\text { To explore Iranian mothers' experiences to receive bad news about } \\
\text { childhood cancer and to summarize suggestions for improving the } \\
\text { delivery of bad news by healthcare providers. }\end{array}$ & $\begin{array}{l}\text { Descriptive qualitative. } \\
\text { P: } 14 \text { mothers. }\end{array}$ & $2^{*}$ \\
\hline (18) & $\begin{array}{c}2000 / \\
\text { Australia }\end{array}$ & $\begin{array}{l}\text { To investigate the level of parent satisfaction with the first } \\
\text { communication of a diagnosis of developmental disability in their } \\
\text { child and the determinants of this satisfaction. }\end{array}$ & $\begin{array}{l}\text { Descriptive qualitative. } \\
\text { P: } 23 \text { parents. }\end{array}$ & $2^{*}$ \\
\hline (19) & $\begin{array}{l}\text { 2008/ } \\
\text { Canada }\end{array}$ & $\begin{array}{l}\text { To assess how well parents recall discussing the diagnosis of cancer } \\
\text { and to summarize suggestions for improvement. }\end{array}$ & $\begin{array}{l}\text { Cross-sectional quantitative. } \\
\text { P: } 116 \text { parents. }\end{array}$ & $4^{*}$ \\
\hline (20) & $\begin{array}{l}\text { 2010/ } \\
\text { Uganda }\end{array}$ & $\begin{array}{l}\text { To explore the challenges of providing HIV counselling and testing } \\
\text { services to children in Uganda. }\end{array}$ & $\begin{array}{l}\text { Descriptive qualitative. } \\
\text { P: } 60 \text { health workers. }\end{array}$ & $2^{*}$ \\
\hline
\end{tabular}




\begin{tabular}{|c|c|c|c|c|}
\hline ID & Year/Country & Objective & Study Design & EL \\
\hline (21) & $\begin{array}{l}\text { 1994/ } \\
\text { Australia }\end{array}$ & $\begin{array}{l}\text { To assess the receptiveness of parents to information given about } \\
\text { their child's life threatening illness. }\end{array}$ & $\begin{array}{l}\text { Descriptive qualitative. } \\
\text { P: } 25 \text { parents. }\end{array}$ & $2^{*}$ \\
\hline (22) & $\begin{array}{l}2000 / \\
\text { USA }\end{array}$ & $\begin{array}{l}\text { To report on parental response to the disclosure and realization that } \\
\text { their child has neurofibromatosis } 1 .\end{array}$ & $\begin{array}{l}\text { Descriptive qualitative. } \\
\text { P: } 18 \text { family members. }\end{array}$ & $2^{*}$ \\
\hline (23) & $\begin{array}{l}\text { 2015/ } \\
\text { Malawi }\end{array}$ & $\begin{array}{l}\text { To explore the experiences of children (10-14 years) living with HIV } \\
\text { following the diagnosis disclosure. }\end{array}$ & $\begin{array}{l}\text { Descriptive qualitative. } \\
\text { P: } 10 \text { children and } 7 \text { caregivers. }\end{array}$ & $2^{*}$ \\
\hline (24) & $\begin{array}{l}\text { 2014/ } \\
\text { Brazil }\end{array}$ & $\begin{array}{l}\text { To learn the experiences of nurses in communicating difficult news } \\
\text { to families of hospitalized children in serious condition or process of } \\
\text { terminality. }\end{array}$ & $\begin{array}{l}\text { Descriptive qualitative. } \\
\text { P: } 9 \text { nursing team professionals. }\end{array}$ & $2^{*}$ \\
\hline (25) & $\begin{array}{c}\text { 2015/ } \\
\text { Tanzania }\end{array}$ & $\begin{array}{l}\text { To assess the determinants and processes of HIV status disclosure to } \\
\text { HIV-infected children aged } 4 \text { to } 17 \text { years receiving HIV care services } \\
\text { at the Baylor College of Medicine Children's Foundation Tanzania, } \\
\text { Centre of Excellence in Mbeya. }\end{array}$ & $\begin{array}{l}\text { Cross-sectional quantitative. } \\
\text { P: } 334 \text { caregivers. }\end{array}$ & $4^{*}$ \\
\hline (26) & $\begin{array}{l}2012 / \\
\text { South Africa }\end{array}$ & $\begin{array}{l}\text { To identify beliefs about disclosing HIV diagnosis to HIV-infected } \\
\text { children among caregivers, health-care providers, and HIV-positive } \\
\text { children who knew their diagnosis. }\end{array}$ & $\begin{array}{l}\text { Descriptive qualitative. } \\
\text { P: } 51 \text { caregivers, } 24 \text { health-care } \\
\text { providers and } 5 \text { children. }\end{array}$ & $4^{*}$ \\
\hline (27) & $\begin{array}{l}2005 / \\
\text { United Kingdom }\end{array}$ & $\begin{array}{l}\text { To identify the child's reactions and behavior following diagnosis, the } \\
\text { parents' views about what to tell their child and factors influencing } \\
\text { parents' communication with the child. }\end{array}$ & $\begin{array}{l}\text { Descriptive qualitative. } \\
\text { P: } 55 \text { parents. }\end{array}$ & $2^{*}$ \\
\hline (28) & $\begin{array}{c}\text { 2016/ } \\
\text { Romania }\end{array}$ & $\begin{array}{l}\text { To explore children's involvement from the perspective of parents } \\
\text { and oncologists. }\end{array}$ & $\begin{array}{l}\text { Descriptive qualitative. } \\
\text { P: } 18 \text { caregivers and } 10 \text { physicians. }\end{array}$ & $2^{*}$ \\
\hline (29) & $\begin{array}{l}\text { 2015/ } \\
\text { Australia and Israel }\end{array}$ & $\begin{array}{l}\text { To examine the relationship between the diagnosis experience and } \\
\text { the disclosure experience for parents of children with developmental } \\
\text { disorders of a genetic etiology known as } 22 q 11.2 \text { deletion syndrome. }\end{array}$ & $\begin{array}{l}\text { Cross-sectional quantitative. } \\
\text { P: } 559 \text { parents and caregivers. }\end{array}$ & $4^{*}$ \\
\hline (30) & $\begin{array}{l}2011 / \\
\text { Jordan }\end{array}$ & $\begin{array}{l}\text { To examine mothers' accounts of communication about cancer } \\
\text { diagnosis to their children, how much children knew about their } \\
\text { illnesses and how satisfied the mothers were with the method they } \\
\text { used in communicating the diagnosis. }\end{array}$ & $\begin{array}{l}\text { Descriptive qualitative. } \\
\text { P: } 51 \text { mothers. }\end{array}$ & $4^{*}$ \\
\hline (31) & $\begin{array}{l}2011 / \\
\text { Saudi Arabia }\end{array}$ & $\begin{array}{l}\text { To elicit the preferences of Saudi mothers about breaking bad news } \\
\text { concerning newborns. }\end{array}$ & $\begin{array}{l}\text { Randomized clinical trial. } \\
\text { P: } 402 \text { mothers. }\end{array}$ & $4^{*}$ \\
\hline (32) & $\begin{array}{l}\text { 2013/ } \\
\text { Brazil }\end{array}$ & $\begin{array}{l}\text { To study the meanings that difficult news assumes when transmitted } \\
\text { by health professionals to relatives of young cystic fibrosis patients. }\end{array}$ & $\begin{array}{l}\text { Descriptive qualitative. } \\
\text { P: } 10 \text { family members. }\end{array}$ & $2^{*}$ \\
\hline (33) & $\begin{array}{l}2005 \\
\text { Thailand }\end{array}$ & $\begin{array}{l}\text { To assess diagnosis disclosure status of perinatally acquired HIV- } \\
\text { infected Thai children. }\end{array}$ & $\begin{array}{l}\text { Cross-sectional quantitative. } \\
\text { P: } 96 \text { primary caregivers }\end{array}$ & $4^{*}$ \\
\hline (34) & $\begin{array}{l}2016 / \\
\text { Sweden }\end{array}$ & $\begin{array}{l}\text { To explore how children with cancer want to receive bad news about } \\
\text { their disease, such as when no more treatment options are available. }\end{array}$ & $\begin{array}{l}\text { Descriptive qualitative. } \\
\text { P: } 10 \text { children }\end{array}$ & $2^{*}$ \\
\hline (35) & $\begin{array}{c}2015 / \\
\text { Colombia }\end{array}$ & $\begin{array}{l}\text { To evaluate the effects of the "DIRE" clinical model of disclosing the } \\
\text { diagnosis of HIV in children under the age of } 17 .\end{array}$ & $\begin{array}{l}\text { Validation study. } \\
\text { P: } 41 \text { health professionals, } 31 \\
\text { caregivers and } 33 \text { children. }\end{array}$ & $2^{*}$ \\
\hline (36) & $\begin{array}{l}\text { 1996/ } \\
\text { Netherlands }\end{array}$ & $\begin{array}{l}\text { To test the hypothesis that being openly informed about the } \\
\text { diagnosis and prognosis benefits the emotional well-being of } \\
\text { children with cancer. }\end{array}$ & $\begin{array}{l}\text { Cross-sectional quantitative. } \\
\text { P: } 56 \text { children and their parents. }\end{array}$ & $6+$ \\
\hline (37) & $\begin{array}{l}2013 / \\
\text { USA }\end{array}$ & $\begin{array}{l}\text { To learn about the experience of receiving a diagnosis from parents } \\
\text { of children with Williams syndrome. }\end{array}$ & $\begin{array}{l}\text { Descriptive qualitative. } \\
\text { P: } 600 \text { families. }\end{array}$ & $2^{*}$ \\
\hline (38) & $\begin{array}{c}2000 / \\
\text { Germany, Italy, } \\
\text { Netherlands, } \\
\text { Portugal, Spain, } \\
\text { Switzerland, } \\
\text { United Kingdom }\end{array}$ & $\begin{array}{l}\text { To describe the extent to which disclosure of infection status and } \\
\text { planning for the future occurs in families with children affected by } \\
\text { HIV in seven European countries. }\end{array}$ & $\begin{array}{l}\text { Cross-sectional quantitative. } \\
\text { P: } 182 \text { family members. }\end{array}$ & $4^{*}$ \\
\hline (39) & $\begin{array}{l}\text { 2014/ } \\
\text { France }\end{array}$ & $\begin{array}{l}\text { To explore lay people's and professionals' views on breaking bad } \\
\text { news to children. }\end{array}$ & $\begin{array}{l}\text { Cross-sectional quantitative. } \\
\text { P: } 170 \text { lay persons, } 33 \text { nurses and } 6 \\
\text { physicians. }\end{array}$ & $4^{*}$ \\
\hline (40) & $\begin{array}{l}\text { Democratic Republic } \\
\text { of Congo }\end{array}$ & $\begin{array}{l}\text { To explore the events before, during, and after disclosure to generate } \\
\text { a narrative of Congolese children's experiences with being told their } \\
\text { HIV status. }\end{array}$ & $\begin{array}{l}\text { Descriptive qualitative. } \\
\text { P: } 8 \text { families ( } 7 \text { children and } 9 \\
\text { caregivers). }\end{array}$ & $2^{*}$ \\
\hline (41) & $\begin{array}{l}2013 / \\
\text { USA }\end{array}$ & $\begin{array}{l}\text { To assess parental perceptions of physicians' interpersonal behaviors } \\
\text { and their role in communication of bad news. }\end{array}$ & $\begin{array}{l}\text { Descriptive qualitative. } \\
\text { P: } 13 \text { parents. }\end{array}$ & $2^{*}$ \\
\hline (42) & $\begin{array}{l}\text { 2012/ } \\
\text { England }\end{array}$ & $\begin{array}{l}\text { To explore the experiences of the 'feedback session' with nine sets of } \\
\text { parents in a community Child and Adolescent Mental Health Service } \\
\text { in North East England. }\end{array}$ & $\begin{array}{l}\text { Descriptive qualitative. } \\
\text { P: } 9 \text { families. }\end{array}$ & $2^{*}$ \\
\hline
\end{tabular}


Chart 1 (concluded)

\begin{tabular}{|c|c|c|c|c|}
\hline ID & Year/Country & Objective & Study Design & EL \\
\hline (43) & $\begin{array}{l}2009 / \\
\text { Ireland }\end{array}$ & $\begin{array}{l}\text { To describe the way that parents are told that their child has } \\
\text { disabilities. }\end{array}$ & $\begin{array}{l}\text { Mixed method. } \\
\text { P: } 1588 \text { professionals and } 584 \\
\text { families. }\end{array}$ & $4^{*}$ \\
\hline (44) & $\begin{array}{l}2006 / \\
\text { USA }\end{array}$ & $\begin{array}{l}\text { To determine parent preferences for prognostic information } \\
\text { about their children with cancer and the results of receiving such } \\
\text { information. }\end{array}$ & $\begin{array}{l}\text { Cross-sectional quantitative. } \\
\text { P: } 194 \text { parents. }\end{array}$ & $4^{*}$ \\
\hline (45) & $\begin{array}{l}\text { 2015/ } \\
\text { Belgium }\end{array}$ & $\begin{array}{l}\text { To explore how parents recall circumstances of the cystic fibrosis } \\
\text { diagnosis and the information they received; and to investigate their } \\
\text { current coping styles. }\end{array}$ & $\begin{array}{l}\text { Descriptive qualitative. } \\
\text { P: } 38 \text { parents. }\end{array}$ & $2^{*}$ \\
\hline (46) & $\begin{array}{l}\text { 2012/ } \\
\text { Egypt }\end{array}$ & $\begin{array}{l}\text { To elicit Egyptian mothers' preferences for how to be told the bad } \\
\text { news about their child's disability. }\end{array}$ & $\begin{array}{l}\text { Cross-sectional quantitative. } \\
\text { P: } 100 \text { mothers. }\end{array}$ & $4^{*}$ \\
\hline (47) & $\begin{array}{c}2011 / \\
\text { United Kingdom }\end{array}$ & $\begin{array}{l}\text { To examine parents' views regarding their preadolescent child's } \\
\text { presence during discussions about serious illnesses. }\end{array}$ & $\begin{array}{l}\text { Descriptive qualitative. } \\
\text { P: } 53 \text { parents. }\end{array}$ & $2^{*}$ \\
\hline (48) & $\begin{array}{l}2008 / \\
\text { USA }\end{array}$ & $\begin{array}{l}\text { To describe parents' perceptions of their conversations with } \\
\text { physicians regarding their child's terminal illness and death in the } \\
\text { pediatric intensive care unit. }\end{array}$ & $\begin{array}{l}\text { Descriptive qualitative. } \\
\text { P: } 56 \text { parents. }\end{array}$ & $2^{*}$ \\
\hline (49) & $\begin{array}{l}2007 / \\
\text { USA }\end{array}$ & $\begin{array}{l}\text { To identify the aspects of physician communication that children } \\
\text { with life-limiting illnesses and their parents perceived to be } \\
\text { facilitative or obstructive in pediatric palliative care. }\end{array}$ & $\begin{array}{l}\text { Descriptive qualitative. } \\
\text { P: } 20 \text { parents. }\end{array}$ & $2^{*}$ \\
\hline (50) & $\begin{array}{c}2002 / \\
\text { United Kingdom }\end{array}$ & $\begin{array}{l}\text { To describe how findings about four preschool children, with } \\
\text { difficulties suspected to lie within the autistic spectrum, were } \\
\text { negotiated with parents. }\end{array}$ & $\begin{array}{l}\text { Descriptive qualitative. } \\
\text { P: } 2 \text { multiprofessional groups. }\end{array}$ & $2^{*}$ \\
\hline
\end{tabular}

Note: ID - reference; $P$ - population; $E L$ - evidence level; * meaning; treatment.

Chart 2- Results of the integrative review of communicating bad news in pediatrics, Brazil, 2018

\begin{tabular}{|c|c|c|c|c|}
\hline \multicolumn{2}{|l|}{ Elements } & Professionals & Family & Children \\
\hline \multicolumn{2}{|l|}{ 葴 } & $\begin{array}{l}\text { work culture }^{(11-12)} \\
\text { privacy }^{(13-14)} \\
\text { training }^{(11-20)}\end{array}$ & $\begin{array}{l}\text { educational level }{ }^{(16,21-28)} \\
\text { family preparation }^{(14,22-23,25-26,29-30)} \\
\text { with companion }^{(13-14,21-22,31-32)}\end{array}$ & $\begin{array}{l}\text { maturity }(21,23,25-27,29-30,33-40) \\
\text { the right to } \text { know }^{(26,34,36)}\end{array}$ \\
\hline \multicolumn{2}{|l|}{$\frac{\grave{d}}{\frac{1}{c}}$} & & $\begin{array}{l}\text { physician }^{(11-16,18-21,23-24,30-32,34-35,37-38,41-49)} \\
\text { nurse }{ }^{(11-16,18-21,23-24,30-32,34-35,37-38,41-49)} \\
\text { other professionals }{ }^{(15,20,35,50)}\end{array}$ & $\begin{array}{l}\text { family with professional } \\
\text { support }^{(15,17,22,25-29,30,33,35-38,40,49-50)} \\
\text { professional }^{(11,20,23,25-26,30,39)}\end{array}$ \\
\hline \multirow{2}{*}{ 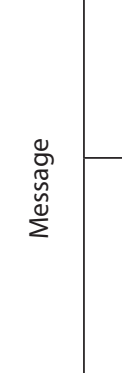 } & 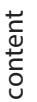 & \multicolumn{3}{|l|}{$\begin{array}{l}\text { diagnoses }^{(11-23,25-38,40-47,49-50)} \\
\text { prognoses }^{(24-25,39,48)}\end{array}$} \\
\hline & 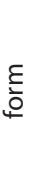 & \multicolumn{3}{|l|}{$\begin{array}{l}\text { honest }^{(11,17,34,43,47-48,50)} \\
\text { empathetic }{ }^{(13,15,17,23,32,41,44-46,48-50)} \\
\text { objective }^{(11,25,32,42,46,49)} \\
\text { hopeful(11,22,34,43-44,50)} \\
\text { available for continuity } \\
(11,14,17,20-21,41,48-49)\end{array}$} \\
\hline 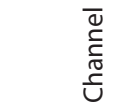 & & \multicolumn{3}{|c|}{$\begin{array}{l}\text { informational material }{ }^{(11,14,16,21-22,25-26,30,37,45)} \\
\text { evaluation of the quantity and quality of the content and pace of information }{ }^{(11,14,16,18-21,28,31,36-37,40-42,45,48)}\end{array}$} \\
\hline 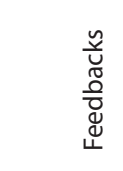 & & $\begin{array}{l}\text { emotion overload }{ }^{(15,22,32)} \\
\text { need to refer children's relatives to } \\
\text { other services }^{(13,22,40)}\end{array}$ & $\begin{array}{l}\text { negative feelings } s^{(11,14,18,20-22,37,42,49)} \\
\text { need for privacy }{ }^{(17)} \\
\text { need for support } \\
\text { seeking other information } \\
\text { sources }^{(11,14,16,20-23,28,34,45)}\end{array}$ & $\begin{array}{l}\text { silencing }^{(23,41)} \\
\text { changes in mood and behavior }^{(11,20,23,30)} \\
\text { participation in self-care }^{(26,33-34,44,49)} \\
\text { questions }^{(28,40)} \\
\text { plans for the future }^{(13,17,23)}\end{array}$ \\
\hline
\end{tabular}




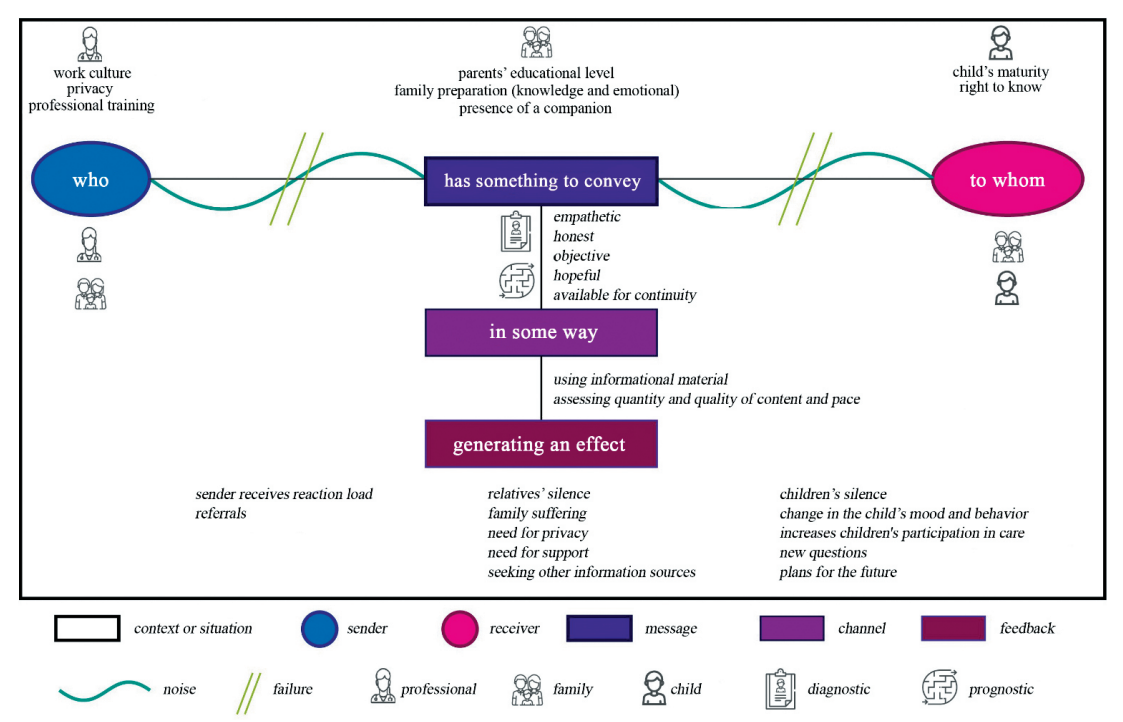

Figure 2 - Elements of communication of the theoretical framework applied in the synthesis of scientific evidence about bad news in pediatrics, Brazil, 2018

\section{DISCUSSION}

For the communication of bad news in pediatrics, we considered the elements that compose the process: context/situation, sender, receiver, message, channel and feedback. In this process, there may be noise and even failures ${ }^{(6-7)}$.

\section{Context of communication}

When analyzing this element in the communicative process in the health and pediatrics area, the scientific evidence indicated a context or situation in which professionals, family members and children are involved.

Regarding the professionals, the work culture is related to the organization and functioning of the team. Communication is facilitated when the common objective is to take good care of the child and the family, combined with mutual support in the team $^{(11)}$. Communication is impaired when professionals believe that the child should not participate in discussions and decisions about prognosis and treatment ${ }^{(12)}$. The lack of privacy (the place where the news is communicated) impairs communication, due either to the absence of the professional or to the structure of the service ${ }^{(13-14)}$.

Professional training involves technical knowledge, updating and professional experience. Participating in work or study groups, scientific events and researches, as well as accessing scientific articles, protocols and guidelines, favors the communicative process ${ }^{(11-13,15-16)}$. Training reflects on the ability to assess the child's and family's preparation to receive the news ${ }^{(17)}$, on the appropriate emotional attitude to position themselves in front of the family and to deal with their own feelings ${ }^{(11,15)}$. Having specialization in the area of the news, length of professional experience and the bond established with the children and their family facilitate communication ${ }^{(18-19)}$. In contrast, communication is impaired when professionals do not have training ${ }^{(12,16,20)}$ or use materials with outdated information ${ }^{(14)}$.

In the family context, the educational level has to be considered, as it enables a better understanding of the message received by the parents ${ }^{(16,21-22)}$, including the interest in searching for other information ${ }^{(22)}$. The family's knowledge about the child's clinical condition $^{(16,21,23-25)}$ or the prognosis of others who are in the same situation ${ }^{(16)}$ makes it easier for the professional to communicate such news. However, many family members do not have sufficient knowledge ${ }^{(26)}$ or, only after receiving the news, they seek to know about the child's diagnosis/prognosis ${ }^{(27)}$. This knowledge is influenced by the time they attend the health service, which implies adaptation to the child's condition ${ }^{(28)}$.

The family's preparation for communicating bad news involves both their knowledge and emotional state, either to receive the news or to share it with the child(26,29-30). When family members say they are unprepared to communicate it to the child, they report an absence of courage and ability ${ }^{(23,25-26)}$. A health education program that provides family members with clinical and social information about the illness could promote knowledge to the family and, consequently, communication to the child ${ }^{(26)}$. Another strategy for preparing families is peer support $\mathrm{t}^{(14,25-26)}$, which provides an exchange of information and experiences ${ }^{(22,26)}$. The presence of a companion, family members or significant people facilitates communication ${ }^{(13-14,21-22,31-32)}$.

In the children context, communication is determined by cognitive maturity ${ }^{(21,26,29-30,33-35)}$. The information provided increases progressively according to the child's age ${ }^{(27,30,36-37)}$, and communication is recommended to start before schooling, between 5 and 7 years old, and to be completed between 10 and 12 years old ${ }^{(21,25-}$ 26,29,38-39). When the child expresses concern about the diagnosis/ treatment/prognosis and questions the truth, communicating was considered more appropriate than saying nothing ${ }^{(23,25-26,33,39)}$. The parents' respect for the child's right to be informed promotes communication $^{(26,34,36)}$, as well as motivations such as preserving trust and acceptance of the illness and treatment ${ }^{(33,36,40)}$.

\section{Sender and Receiver}

It was evidenced that the communication should be made, preferably, by those who accompany the child ${ }^{(32,46,49)}$. There is a consensus that the communication that is up to the physician is the most technical one, such as the results of tests, the diagnosis and the prognosis $\mathrm{s}^{(13,17,24,32,46,48-49)}$.

Regarding the interdisciplinary approach ${ }^{(13,17-18)}$, when the sender of the communication are the other professionals, they prefer not to be the first to deliver the bad news. Nurses feel safer to talk to family members after the physician has already communicated the most difficult news and the family members are aware of the clinical condition. The professionals' difficulties are related to the abilities of communication, of dealing with their own feelings and with the feelings of others ${ }^{(24)}$.

It was evidenced that the professionals of the team maintain the communication with information so that the family understands 
about the child's diagnosis/prognosis, and they provide guidance on how to proceed with confirmatory and/or complementary tests, treatment and follow-up in the health service ${ }^{(13,16,32,48)}$. Preferably, the diagnosis is communicated to the children's parents ${ }^{(31,49)}$ when they are accompanied by a support person ${ }^{(13,31,46)}$. Then, if the parents wish to, they can communicate it to the rest of the family, and can request support from the professionals ${ }^{(17)}$.

When the bad news has to be communicated to the child, the family should be the one to do it, preferably by the parents together ${ }^{(15,17,22,25-30,33,35-38,40,49-50)}$, with support from the professionals $^{(15,17,25-26,28,33,38,49-50)}$. Studies showed that the parents talked to the child, especially the mothers, after a professional had already done $\mathrm{it}^{(40)}$, and they included other significant family members, those who knew the diagnosis and participated in the child's care, such as the maternal grandmother ${ }^{(45)}$. Sometimes, the family requested subsidies from the professional, considering the need for answers to the children's questions, or to get prepared to break the news ${ }^{(25,45)}$.

When the child and the family receive the news at the same time, they have the possibility to support each other ${ }^{(34,47,49)}$. Children expect to receive the news in the presence of their parents ${ }^{(34)}$, and parents, on the other hand, prefer to receive the news first in order to filter the information for the child ${ }^{(30,49)}$.

\section{Message}

As for the message, that is, something to be conveyed, the diagnoses were identified as cancer ${ }^{(12-13,15,17,19,21,27-28,30,34,36,44,47)}$, $\operatorname{HIV}^{(20,23,25-26,33,35,38,40)}$, genetic alteration ${ }^{(14,22,29,31,37,46)}$, cystic fibro$\operatorname{sis}^{(16,32,45)}$, disabilities (physical, intellectual, sensory or autism) $(13,18,42,43,50)$ and $\operatorname{cardiac}^{(41,49)}$, renall ${ }^{(41)}$ and neurological ${ }^{(41)}$ conditions. Among the prognoses, terminality predominated ${ }^{(24-25,39,48)}$. The communication must be honest, which was evidenced as considering the particularities of the children and their family and telling the family members about the child's health status clearly, without lying or omitting information concerning the diagno$\operatorname{sis}^{(11,17,34,43,47-48,50)}$. The message communicated in an objective or direct manner must contain all information for the understanding of the child's diagnosis, using a clear language and avoiding scientific terminology $(11,25,32,42,46,49)$.

It is worthy to note that empathy includes being prepared to listen, addressing the subject calmly, being sensitive when communicating the bad news, providing comfort, consolation and confidence, developing bonds and considering feelings, concerns and consequences ${ }^{(13,15,17,23,32,41,44-46,49-50)}$. Family members value non-verbal language and associate it with confidence in the professional, manifested through eye contact, tone of voice and facial expressions ${ }^{(41,48)}$.

Parents ${ }^{(44,50)}$ and children ${ }^{(34)}$ value knowing the prognosis with a perspective of hope, as long as it is honest ${ }^{(43)}$. A pessimistic perspective, with information and facts about the worst cases, generates dissatisfaction ${ }^{(22,43)}$. However, the team finds it difficult not to show a pessimistic perspective when it comes to recurrence ${ }^{(11)}$.

Parents indicate the importance of having the health professional available to talk to the family, in more detail and calm$\mathrm{ly}^{(17,21,41,48-49)}$, as their needs may change over time ${ }^{(14)}$. In one study, the professionals made themselves available through telephone contact $^{(11)}$. Professionals consider it important to monitor the repercussions, since children may not fully express themselves at the time they receive the news ${ }^{(20)}$.

\section{Channel}

Parents expect professionals to use informational material to communicate the bad news ${ }^{(30)}$, and they value receiving such materials, such as leaflets from local and national support organizations, as an incentive to seek new information ${ }^{(16,37,45)}$. However, when they receive scary material, they consider it inappropriate and are not able to complete the reading ${ }^{(22)}$. Family members look for sources to understand clinical and social aspects of the illness, and use libraries, magazines, newspapers, internet and support groups ${ }^{(14,16,45)}$.

For children, drawings ${ }^{(25)}$, specific programs ${ }^{(26)}$ or books were used as metaphors for the situation experienced by the child(30). Parents expressed incipience and obsolescence of the literature for their children's age group ${ }^{(21,37)}$. On the other hand, living with other children who have the same diagnosis can create insecurity ${ }^{(11,22)}$.

The quantity and quality of information provided by parents to children increases according to their age ${ }^{(36)}$. Parents expect the disclosure to start partially in an attempt to protect the children from association with death, but they recognize that they cannot protect the children from distressing information ${ }^{(28)}$. The family expects the professionals to provide information at the pace for which they are prepared, each one in their own time and with the appropriate amount of information ${ }^{(14,48)}$, respecting the parents knowledge ${ }^{(18,41)}$. In some studies, parents reported receiving insufficient information, and for this reason they needed to ask questions for a better understanding ${ }^{(21,37)}$. Family members also valued having a focus of discussion at each meeting, talking about things as they happen, in detail $19,31,42,45)$.

Professionals state that, in order to assess the amount of information provided, it is necessary to consider that children are more sensitive and need adults who are patient ${ }^{(20)}$. Sometimes, professionals focus the guidance on the family, for considering that children are too young to understand ${ }^{(11)}$. They consider it a challenge to determine the amount of information they should provide, as it depends on the family history, on the child's current health and curiosity, and on the parents' education and emotional level ${ }^{(16,40)}$.

\section{Effects}

The effects related to professionals run through the sender receiving the reaction load ${ }^{(22,32)}$. Professionals recognize the burden and prefer not to be alone at that moment ${ }^{(15)}$. Another effect is the need for referrals for parents to talk to another professional ${ }^{(13,22,40)}$.

Regarding family members, there are evidence of different feelings: insecurity ${ }^{(11,22)}$, suffering ${ }^{(11,14,18,21,37,42,49)}$, relief ${ }^{(21,42)}$, difficulty in acceptance ${ }^{(20)}$. Suffering ${ }^{(11,14,18,21,37,42,49)}$ is related to blame, anger, sadness, distress, devastation, shock, rejection, denial, concern, uncertainty and injustice. The feelings extend beyond the moment, and the parents feel lost and without support ${ }^{(13,22,42)}$. They need privacy $^{(17)}$ and support from the network ${ }^{(11,21)}$, especially from other family members ${ }^{(17,23,42,45)}$ and specialized support ${ }^{(13-14,23,32)}$. They 
value the support of the multidisciplinary team, with a physician, speech therapist, social worker, nurse and psychologist, which conveys the feeling of more people involved and united with the same commitment ${ }^{(13-14,23,32)}$. The prognosis information causes greater suffering when provided by non-specialized professionals who do not monitor the child ${ }^{(13,32)}$. In order to communicate the bad news to other family members, parents expect professional help ${ }^{(17)}$ and value receiving materials to help them explain the situation $^{(42,45)}$. Parents seek other sources of information ${ }^{(14,16,22,28,45)}$ and encourage the child to seek knowledge, to question ${ }^{(28)}$ and to have greater awareness for the treatment ${ }^{(11,20-21,23,28,34)}$.

Regarding the children, there are evidence of effects such as: suffering $^{(11,20,23,30)}$, silence ${ }^{(23,40)}$, increased participation ${ }^{(26,33,34,40,49)}$ in care, curiosity for new questions $\mathrm{s}^{(28,40)}$ and plans for the future $\mathrm{e}^{(13,17,23)}$. They suffer because their caregivers delayed the disclosure of the diagnosis, for fear of being stigmatized and for having to keep secrets $^{(23)}$, for the psychological and social consequences ${ }^{(11)}$, for the uncertain future and the possibility of dying ${ }^{(20)}$.

\section{Noise and failures}

The communication process can happen with noises, among which the psychological and semantic classifications were evidenced. The psychological one was identified when the professional sender has to be able to deal with their feelings and with the emotional reaction of the receiver ${ }^{(13,16-17,24,26,32,40,47)}$. Children can be frightened or confused when they listen to professionals about the possibility of dying, and sometimes family members have to comfort them ${ }^{(47)}$. Parents suffer and so do children, wondering who is going to help whom ${ }^{(40)}$.

The professionals' rationality makes it difficult to observe the receiver's emotions ${ }^{(17,32,45,49)}$. The way in which they convey information demonstrates the professional's degree of interest to the child and themselves ${ }^{(16,45)}$. Family members expect their emotions to be considered by the professionals in the face of repercussions such as uncontrollable crying and disorientation, which prevent the appointment from continuing ${ }^{(32)}$ and inhibit the ability to process information ${ }^{(16)}$.

In semantic noises, terms used by professionals that do not make sense to family members ${ }^{(13-14,16,21,27,32,42,45,48-49)}$ were identified. There were some conflicting and confusing information, when provided by more than one person ${ }^{(21)}$, or when the diagnosis or prognosis was conclusive ${ }^{(27,48-49)}$. Avoiding the name of the illness, especially when communicating with the child, also generates noise, such as when parents use nicknames or synonyms in an attempt to facilitate understanding or to protect the child from suffering because of the illness or prognosis ${ }^{(17,27,30)}$.

In addition, communication can be flawed when established by non-specialized professionals ${ }^{(11,13,16,20,32)}$ and when the approach is not multidisciplinary. Since it is attributed to the physician, the communication contemplates only the results of examinations and the child's clinical profile ${ }^{(24)}$. Professionals' lack of confidence in themselves can cause problems in communication, since they need to combine affection and the technical skill to convey confidence, comfort and safety ${ }^{(11)}$. Some professionals prefer to soften the truth in order not to cause hopelessness in family members ${ }^{(24)}$, whereas others turn away from the child and their relatives in the face of their feelings and difficulty in communicating bad news ${ }^{(11,24,28)}$.

The fact that parents do not want the children to know their diagnosis generates communication failure ${ }^{(17,20,23,26,28,30)}$, as they minimize, silence ${ }^{(24,39-40)}$ or provide misleading information ${ }^{(14,30,33,40,42,48)}$. Physicians report refraining from communicating to children, due to uncertainty about parents' agreement or their request ${ }^{(20,28)}$. Among the reasons for not wanting to tell are stigma ${ }^{(14,20,23,26)}$, fear of isolation ${ }^{(14,20,23,26)}$, fear of causing suffering to the child ${ }^{(23,26,33)}$, wanting to prepare them ${ }^{(17,30)}$, concern that the child will not keep the secret ${ }^{(33)}$, not recognizing the child's right to know the diagnosis $^{(33)}$ and feeling guilty ${ }^{(20,33)}$. Parents without enough information about the illness try to hide the facts from the child ${ }^{(26)}$.

Among the failures, organizational barriers were evidenced, such as the service not allowing fathers to stay in the hospital with the child, therefore, only mothers accompanied their children in the hospital ${ }^{(17)}$. It is worthy to mention situations in which communication failed for happening indirectly, for example, when parents discovered the diagnosis when hearing conversations between physicians ${ }^{(17)}$, and when children discovered the diagnosis by reading or hearing comments about the illness in the environment they were $\mathrm{in}^{(25,30,41)}$ or by other people $\mathrm{e}^{(25,41)}$.

\section{Limitations of the study}

Although the review question has been answered, we understand that other primary studies could be identified by searching other databases, even though the main health databases have been accessed. We understand that the option for not consulting gray literature, such as theses and dissertations, may have led to not including unpublished results in the form of articles. We recognize that this revision has limitations with respect to the complexity of analyzing articles that used different methodological approaches, in addition to the plurality of communication propositions that expand from the linear articulation among the elements to the interaction.

\section{Contributions to the area of nursing, health or public policies}

The synthesis of the communication elements indicates contributions for health professionals to communicate bad news. We recommend an interdisciplinary team that includes, especially, the professional who has a bond with the family and the child, who is often the nurse.

The results reinforce the need for investments in the communication of bad news, considering the needs of the professional, the family and the child in order to obtain better effects. For professionals, the promotion of training (message and manner) and an environment that guarantees privacy are indicated. For the family, the evidence point to the need for preparation strategies before communication and the presence of a companion at the time of communication, which should be recommended by the policy and assistance guidelines, including the recognition of the child's right to know about their health condition and the assessment of their maturity to receive the information. This demands commitment from the political, assistance and education bodies, in order to contemplate the issue in professional training and qualification. 


\section{CONCLUSIONS}

The described evidence indicated that the communication of bad news in pediatrics involves all elements of the traditional framework of Lasswell ${ }^{(6)}$ adopted for the extraction and discussion of the data in this review. The context of the news indicated the need to prepare the team, the family and the child. The diagnoses of cancer and HIV and the prognosis of terminality were considered bad or difficult news. The way of communicating must be honest, empathetic and objective, aiming to maximize better effects on the child, family and professionals. In order to minimize noise, it is necessary to use language and technique to communicate according to the family's level of education and the child's maturity. In order to avoid failures, it is essential that professionals and family members recognize the children's right to know about their condition, breaking the silence, the misleading information and the discovery from other people. It is urgent to promote the co-responsibility of institutions and participants in this process, aiming to minimize noise and avoiding failures. We recognize that, for the application of this synthesis of knowledge in the practice of communicating bad news in pediatrics, it is possible to consider other communication propositions, in response to the traditional framework, that recognize that communication is, most importantly, interaction without established limits for the beginning or end of the interpersonal relationship.

\section{FUNDING}

Coordination for the Improvement of Higher Education Personnel, Brazil - Funding Code 001.

\section{ACKNOWLEDGEMENT}

The authors would like to thank the support of the Educational Technology Center (ETC) of the Federal University of Santa Maria (UFSM/RS) in the creation of Figure 2 - Elements of communication of the theoretical framework applied in the synthesis of scientific evidence about bad news in pediatrics, especially to the designer Carlo de Moraes.

\section{REFERENCES}

1. Singh D, Agarwal D. Breaking bad news in clinical setting: a systematic review. Indian J Appl Res [Internet]. 2018 [cited 2019 Jan 17];7(12): 29-32. Available from: https://wwjournals.com/index.php/ijar/article/view/122

2. Armas A, Meyer SB, Corbett KK, Pearce AR. Face-to-face communication between patients and family physicians in Canada: a scoping review. Patient Educ Couns [Internet]. 2018 [cited 2018 Jun 20];101(5):789-803. Available from: https://www.ncbi.nlm.nih.gov/ pubmed/29173960

3. Fontes $\mathrm{CMB}$, Menezes DV, Borgato $\mathrm{MH}$, Luiz MR. Comunicação de más notícias: revisão integrativa de literatura na enfermagem. Rev Bras Enferm. 2017;70(5):1089-95. doi: 10.1590/0034-7167-2016-0143

4. Gold R, Gold A. Delivering bad news: attitudes, feelings and practice characteristics among speech-language pathologists. Am J SpeechLanguage Pathol. 2018;27(1):108-22. doi: 10.1044/2017_AJSLP-17-0045

5. Crosnier-Schoedel C, Trocmé N, Carbajal R, Leverger G. Pediatrician's experience in announcing bad news. Arch Pediatr. 2018;25(2):100-106. doi:10.1016/j.arcped.2017.11.006

6. Martino LMS. Teoria da Comunicação: ideias, conceitos e métodos. Ed vozes, p.288, 2017.

7. Lasswell, Harold D. The structure and function of communication in society. Illetişim kuram ve araştırma dergisi Sayı 24 Kış-Bahar [Internet]. 2007[cited 2018 Jun 20];215-28; Available from: https://pracownik.kul.pl/files/37108/public/Lasswell.pdf

8. Johnson J, Panagioti M. Interventions to improve the breaking of bad or difficult news by physicians, medical students, and interns/ residents: a systematic review and meta-analysis. Acad Med. 2018;93(9):1400-12. doi: 10.1097/ACM.0000000000002308.

9. Ganong LH. Integrative reviews of nursing research. Res Nurs Health. 1987;10 (1):1-11. doi: 10.1002/nur.4770100103

10. Melnyk BM, Fineout-Overholt E, Stillwell SB, Williamson KM. Evidence-based practice: step by step: igniting a spirit of inquiry: an essential foundation for evidence-based practice. Am J Nurs [Internet]. 2009 [cited 2017 Nov 15];109(11):49-52 Available from: https://www.ncbi.nlm. nih.gov/pubmed/19858857

11. Afonso SBC, Minayo MCS. Relações entre oncohematopediatras, mães e crianças na comunicação de notícias difíceis. Ciên Saúde Coletiva [Internet]. 2017 [cited 2018 Jun 28];22(1):53-62. Available from: www.scielo.br/pdf/csc/v22n1/1413-8123-csc-22-01-0053.pdf

12. Parsons SK, Saiki-Craighill S, Mayer DK, Sullivan AM, Jeruss S, Terrin N, et al. Telling children and adolescent about their cancer diagnosis: cross-cultural comparisons between pediatric oncologists in the US and Japan. Psycho-Oncol[Internet]. 2007 [cited 2018 Jan 10];16(1):60-8. Available from: https://www.ncbi.nlm.nih.gov/pubmed/16874746

13. Gilbey P. Qualitative analysis of parents' experience with receiving the news of the detection of their child's hearing loss. Int J Pediatr Otorhinolaryngol [Internet]. 2010 [cited 2017 Jul 16];74(3):265-70. Available from: https://www.ncbi.nlm.nih.gov/pubmed/20042242

14. Hill V, Sahhar M, Aitken M, Savarirayan R, Metcalfe S. Experiences at the time of diagnosis of parents who have a child with a bone dysplasia resulting in short stature. Am J Med Genet A [Internet]. 2003 [cited 2018 Jun 15];122A(2):100-7. Available from: https://www.ncbi.nlm.nih. gov/pubmed/12955760

15. Stenmarker M, Hallberg U, Palmérus K, Márky I. Being a messenger of life-threatening conditions: experiences of pediatric oncologists. Pediatr Blood Cancer [Internet]. 2010 [cited 2017 Jun 18];55(3):478-84. Available from: https://www.ncbi.nlm.nih.gov/pubmed/20658619 
16. Finan C, Nasr SZ, Rothwell E, Tarini BA. Primary care providers'experiences notifying parents of cystic fibrosis newborn screening results. Clin Pediatr (Phila) [Internet]. 2014 [cited 2018 Jan 16];54(1):67-75. Available from: https://www.ncbi.nlm.nih.gov/pubmed/25104730

17. Aein F, Delaram M. Giving bad news: a qualitative research exploration. Iran Red Crescent Med J [Internet]. 2014 [cited 2018 Jun 16];16(6):e8197. Available from: https://www.ncbi.nlm.nih.gov/pmc/articles/PMC4102999/

18. Hasnat MJ, Graves P. Disclosure of developmental disability: a study of parent satisfaction and the determinants of satisfaction. J Paediatr Child Health [Internet]. 2000 [cited 2018 Jan16];36(1):32-5. Available from: https://www.ncbi.nlm.nih.gov/pubmed/10723688

19. Parker TM, Johnston DL. Parental perceptions of being told their child has cancer. Pediatr Blood Cancer [Internet]. 2008 [cited 2017 Jan 26];51(4):531-4. Available from: https://www.ncbi.nlm.nih.gov/pubmed/18623217

20. Rujumba J1, Mbasaalaki-Mwaka CL, Ndeezi G. Challenges faced by health workers in providing counselling services to HIV-positive children in Uganda: a descriptive study. J Int AIDS Soc [Internet]. 2010 [cited 2017 Jan 22];13:9. Available from: https://www.ncbi.nlm.nih.gov/ pubmed/20205937

21. Eden OB, Black I, MacKinlay GA, Emery AE. Communication with parents of children with cancer. Palliat Med [Internet]. 1994 [cited 2018 Jul 22];8(2):105-14. Available from: https://www.ncbi.nlm.nih.gov/pubmed/8081551

22. Ablon J. Parents' responses to their child's diagnosis of neurofibromatosis 1. Am J Med Genet [Internet]. 2000 [cited 2018 Jan 23];93(2):13642. Available from: https://www.ncbi.nlm.nih.gov/pubmed/10869117

23. Phuma-Ngaiyaye EE, Dartey AF. Experiences of children living with HIV and AIDS following their diagnosis disclosure in Mzuzu, Malawi. Vulnerable Child Youth Stud. 2015;10(4):357-65. doi: 10.1080/17450128.2015.1083639

24. Gomes GC, Xavier DM, Mota MS, Salvador MS, Silveira RS, Barlem ELD. Dando notícias difíceis à família da criança em situação grave ou em processo de terminalidade. Rev Enferm UERJ [Internet]. 2014 [cited 2017 Jun 26];22(3):347-52. Available from: https://pesquisa.bvsalud.org/ portal/resource/pt/bde-27990

25. Nzota MS, Matovu JKB, Draper HR, Kisa R, Kiwanuka SN. Determinats and processo f HIV status disclosure to HIV-infected children aged 4 to 17 years receiving HIV care services at Baylor College of Medicine Children's Foundation Tanzania, Centre of Excellence (COE) in Mbeya: cross-sectional study. BMC Pediatrics [Internet]. 2015 [cited 2018 Jan 13];15:81. Available from: https://www.springermedizin.de/ determinants-and-processes-of-hiv-status-disclosure-to-hiv-infec/9746990

26. Heeren GA, Jemmott JB 3rd, Sidloyi L, Ngwane Z. Disclosure of HIV diagnosis to HIV-infected children is South Africa: focus groups for intervention development. Vulnerable Child Youth Stud [Internet]. 2012 [cited 2017 Dec 12];7(1):47-54. Available from: https://www.ncbi. nlm.nih.gov/pubmed/22468145

27. Clarke SA, Davies H, Jenney M, Glaser A, Eiser C. Parental communication and children's behaviour following diagnosis of childhood leukaemia. Psycho-Oncol [Internet]. 2005 [cited 2018 Jul 13]14(4):274-81. Available from: https://www.ncbi.nlm.nih.gov/pubmed/15386768

28. Badarau DO, De Clercq E, Wangmo T, Dragomir M, Miron I, Kühne T, et al. Cancer care in Romania: challenges and pitfalls of children's and a adolescent's multifaceted involvement. J Med Ethics [Internet]. 2016 [cited 2018 Jan 13];42(12):757-61. Available from: https://www.ncbi. nlm.nih.gov/pubmed/27697792

29. Goodwin J, Schoch K, Shashi V, Hooper SR, Morad O, Zalevsky M, et al. A tale worth telling: the impacto f the diagnosis experience on disclosure of genetic disorders. J Intellect Disabil Res [Internet]. 2015 [cited 2018 Jan 18];59(5):474-86. Available from: https://www.ncbi.nlm. nih.gov/pubmed/25059276

30. Arabiat DH, Alqaissi NM, Hamdan-Mansour AM. Children's knowledge of cancer diagnosis and treatment: jordanian mothers' perceptions and satisfaction with the process. Int Nurs Rev [Internet]. 2011 [cited 2018 Jun 13];58(4):443-9. Available from: https://www.ncbi.nlm.nih. gov/pubmed/22092322

31. Al-Abdi SY, Al-Ali EA, Daheer MH, Al-Saleh YM, Al-Qurashi KH, Al-Aamri MA. Saudi mothers' preferences about breaking bad news concerning newborns: a structured verbal questionnaire. BMC Medical Ethics [Internet]. 2011 [cited 2018 Dec 13];12:15. Available from: https://www.ncbi.nlm.nih.gov/pubmed/21861876

32. Afonso SBC, Mitre RMA. Noticias difíceis: sentidos atribuídos por familiares de crianças com fibrose cística. Ciên Saúde Coletiva [Internet]. 2013 [cited 2018 Jan 13];18(9):2605-13. Available from: www.scielo.br/pdf/csc/v18n9/v18n9a15.pdf

33. Boon-Yasidhi V, Kottapat U, Durier Y, Plipat N, Phongsamart W, Chokephaibulkit K, et al. Diagnosis disclosure in HIV-infected Thai children. J Med Assoc Thai [Internet]. 2005 [cited 2018 Jan 26];88(8):S100-5. Available from: https://www.ncbi.nlm.nih.gov/pubmed/16858851

34. Jalmsell L, Lövgren M, Kreicbergs U, Henter Jl, Frost BM. Children with cancer share their views: tell the truth but leave room for hope. Acta Paediatr [Internet]. 2016 [cited 2018 Jan 16];105(9):1094-9. Available from: https://www.ncbi.nlm.nih.gov/pubmed/27272911

35. Trejos AM, Reyes L, Bahamon MJ, Alarcón Y, Gaviria G. Effects in the adherence treatment and psychological adjustment after the disclosure of HIV/AIDS diagnosis with the "DIRE" clinical model in Colombian children under 17. Rev Child Infectol. 2015;32(4):408-15. doi: 10.4067/ S0716-10182015000500007

36. Last BF, van Veldhuizen AMH. Information about diagnosis and prognosis related to anxiety and depression in children with cancer aged 8-16 years. EJC. 1996;32(2):290-4. Available from: doi: 10.1016/0959-8049(95)00576-5

37. Waxler JL, Cherniske EM, Dieter K, Herd P, Pober BR. Hearing from parents: the impacto f receiving the diagnosis of Williams syndrome in their child. Am J Med Genet A [Internet]. 2013 [cited 2018 Jan 19];161A(3):534-41. Available from: https://www.ncbi.nlm.nih.gov/ pubmed/23401422 
38. Thorne C, Newell ML, Peckham CS. Disclosure of diagnosis and planning for the future in HIV-affected families in Europe. Child Care Health Dev. 2000;26(1):29-40. doi: 10.1046/j.1365-2214.2000.00128.x

39. Muñoz Sastre MT, Sorum PC, Mullet E. Lay people's and health professionals'views about breaking bad news to children. Child Care Health Dev [Internet]. 2014 [cited 2018 Jan 26];40(1):106-14. Available from: https://www.ncbi.nlm.nih.gov/pubmed/22928950

40. Vaz LM, Eng E, Maman S, Tshikandu T, Behets F. Telling children they have HIV: lessons learned from findings of a qualitative study in SubSaharan Africa. AIDS Patients Care STDS [Internet]. 2010 [cited 2018 Jun 12];24(4):247-56. Available from: https://www.ncbi.nlm.nih.gov/ pubmed/20397899

41. Orioles A, Miller VA, Kersun LS, Ingram M, Morrison WE. "To be a phenomenal doctor you have to be the whole package": physicians' interpersonal behaviors during difficult conversations in pediatrics. J Palliat Med [Internet]. 2013 [cited 2018 Jun 12];16(8):929-33. Available from: https://www.ncbi.nlm.nih.gov/pubmed/23808643

42. Abbott M, Bernard P, Forge J. Communicating a diagnosis of autism spectrum disorder-a qualitative study of parents' experiences. Clin Child Psychol Psychiatr [Internet]. 2012 [cited 2018 Jan 26];18(3):370-82. Available from: https://www.ncbi.nlm.nih.gov/pubmed/22904114

43. Harnett A, Tierney E, Guerin S. Convention of hope-communicating positive, realistic messages to families at the time of a child's diagnosis with disabilities. British J Learn Disabil. 2009;37:257-64. doi: 10.1111/j.1468-3156.2009.00580.x

44. Mack JW, Wolfe J, Grier HE, Cleary PD, Weeks JC. Communication about prognosis between parents and physicians of children with cancer: parents preferences and the impact of prognostic information. J Clin Oncol [Internet]. 2006 [cited 2017 Jun 26];24(33):5265-70. Available from: https://www.ncbi.nlm.nih.gov/pubmed/17114660

45. Havermans T, Tack J, Vertommen A, Proesmans M, de Boeck K. Breaking bad news, the diagnosis of cystic fibrosis in childhood. J Cyst Fibros [Internet]. 2015 [cited 2018 Jun 16];14(4):540-6. Available from: https://www.ncbi.nlm.nih.gov/pubmed/25563520

46. Abdelmoktader AM, Abd Elhamed KA. Egyptian mothers' preferences regarding how physicians break bad news about their child's disability: A structured verbal questionnaire. BMC Med Ethics [Internet]. 2012 [cited 2018 Jan 16];13:14. Available from: https://www.ncbi. nlm.nih.gov/pubmed/22747832

47. Young B, Ward J, Salmon P, Gravenhorst K, Hill J, Eden T. Parents' experiences of their children's presence in discussions with physicians about leukemia. Pediatr [Internet]. 2011 [cited 2018 Jun 25];127(5):1230-8. Available from: pediatrics.aappublications.org/content/127/5/e1230

48. Meert KL, Eggly S, Pollack M, Anand KJS, Zimmerman J, Carcillo J, et al. Parents's perspectives on physician-parent communication near the time of a child's death in the pediatric intensive care unit. Pediatr Crit Care Med [Internet]. 2008 [cited 2018 Jun 25];9(1):2-7. Available from: https://www.ncbi.nlm.nih.gov/pubmed/18477906

49. Hsiao JL, Evan EE, Zeltzer LK. Parent and child perspectives on physician communication in pediatric palliative care. Palliat Support Care [Internet]. 2007 [cited 2017 Jan 13];5(4):355-65. Available from: https://www.ncbi.nlm.nih.gov/pubmed/18044413

50. Bartolo PA. Communicating a diagnosis of developmental disability to parents: multiprofessional negotiation frameworks. Child Care Health Dev [Internet]. 2002 [cited 2017 Jan 15];28(1):65-71. Available from: https://www.ncbi.nlm.nih.gov/pubmed/11856189 